\title{
Acetamiprid-induced Cyto- and Genotoxicity in the AR42J Pancreatic Cell Line
}

\section{AR42J Pankreas Hücre Hattında Asetamiprid ile İndüklenen Sito- ve Genotoksisite}

\author{
(1) Mehtap KARA*, (1) Ezgi ÖZTAȘ, (1) Gül ÖZHAN \\ Istanbul University Faculty of Pharmacy, Department of Pharmaceutical Toxicology, İstanbul, Turkey
}

\begin{abstract}
Objectives: Neonicotinoid insecticides, 30\% of insecticides marketed worldwide, have selective toxicity on insects through $\alpha 4 p 2$ nicotinic acetylcholine receptors. Although it is known that acetamiprid exerts toxicity on several organ systems, its toxic effects on the pancreas and its mechanism of action have not been clarified yet. Therefore, in the present study, the cytotoxic and genotoxic potentials of acetamiprid on the AR42 $\mathrm{J}$ pancreatic cell line were evaluated.

Materials and Methods: The (3-[4,5-dimethylthiazol-2-yl]-2,5 diphenyl tetrazolium bromide) (MTT) assay and comet assay were conducted for the cyto- and genotoxicity evaluations, respectively. Reactive oxygen species (ROS) production was assessed by flow cytometry and glutathione (GSH) levels were determined by ELISA for oxidative damage potential, which is thought to be an underlying mechanism of cyto-/genotoxic effects.

Results: To reveal the dose-response relationship the concentration range of 1-6 mM was selected for the assays. Cell viability decreased in a dosedependent manner and the inhibitory concentration 50 value was calculated as $12.61 \mathrm{mM}$ by the MTT assay. Acetamiprid induced DNA damage in all concentrations tested in a dose-depending manner. The mean tail intensity values were 3.84 and $\leq 32.96$ for the control and exposure groups, respectively. There was no significant difference for ROS production; however, the GSH level was reduced at the highest concentration.

Conclusion: It is thought that the present study will contribute to the literature due to the lack of data on the potential toxic effects of acetamiprid on the pancreas. To better understand acetamiprid toxicity, further studies including a wide range of mechanistic parameters are needed.
\end{abstract}

Key words: Acetamiprid, AR42J pancreatic cell line, cytotoxicity, genotoxicity, oxidative damage

öz

Amaç: Neonikotinoid insektisidler dünya piyasasındaki insektisidlerin \%30'luk kısmını oluşturur ve etkilerini seçici olarak böceklerdeki $\alpha 4 p 2$ nikotinik asid reseptörünü inhibe ederek gösterirler. Asetamipridin çeşitli organ ve sistemler üzerine toksik etkileri biliniyor olmasına karşın, pankreas üzerindeki etkisi ve etki mekanizması bilinmemektedir. Bu çalışmada, asetamipridin AR42J pankreas hücre hattı üzerinde sitotoksik ve genotoksik etkileri araştırıldı.

Gereç ve Yöntemler: Sitotoksisite ve genotoksisite değerlendirmesi için (3-[4,5-dimetiltiyazol-2-il]-2,5 difenil tetrazolyum bromür) (MTT) ve comet analizi gerçekleştirildi. Reaktif oksijen türlerinin (ROS) oluşumu akış sitometresi ile, glutatyon (GSH) düzeyi ise ELISA yöntemi ile belirlenmiştir.

Bulgular: MTT sitotoksisite analizine gore, hücre canlılı̆ının doza bağımlı olarak azaldığı gözlendi ve inhibitör konsantrasyon 50 değeri 12,61 mM olarak tespit edildi. Analizlerde doz yanıt ilişkisini gösterebilmek için 1-6 mM doz aralığı seçildi. Asetamiprid DNA hasarını doza bağımlı olarak artırdı ve ortalama kuyruk yoğunluğu değerleri kontrol ve çalışma grupları için sırasıyla 3,84 ve $\leq 32,96$ olarak belirlendi. ROS üretimi açısından gruplar arasında anlamlı bir fark gözlenmemiş, GSH değerinin en yüksek doz grubunda anlamlı olarak çok düştüğü tespit edilmiştir.

Sonuç: Bu çalışma literatürde asetamipridin pankreas üzerine olası toksik etkisine yönelik eksik olan verilere katkı sağlamaktadır. Asetamipridin toksik etkisinin detaylandırılması için daha geniş çaplı mekanizma temelli çalışmalara intiyaç bulunmaktadır.

Anahtar kelimeler: Asetamiprid, AR42J pankreas hücre hattı, sitotoksisite, genotoksisite, oksidatif hasar

*Correspondence: E-mail: matost@gmail.com, Phone: +90 5073492478 ORCID-ID: orcid.org/0000-0001-7764-5593

Received: 04.03.2019, Accepted: 04.04.2019

๑Turk J Pharm Sci, Published by Galenos Publishing House. 


\section{INTRODUCTION}

Many xenobiotics pose important threats for both human and environmental health. Pesticides, the most common pollutants, are harmful for biological structures via several mechanisms in acute and long-term exposure.-3 Neonicotinoid pesticides as a new class of insecticides that are commonly used instead of organophosphate, and carbamate pesticides have selectively neurotoxic effects on nicotinic acetylcholine receptor. Neonicotinoid pesticides are highly effective insecticides that can disperse in all parts of plants, plant fluids, and fruits that grow on plants. Recent studies revealed that neonicotinoid pesticides can be associated with several adverse effects including decreased sperm production and function, decreased pregnancy rates, increased embryo death, stillbirth, and premature birth in vertebrate and invertebrate species. ${ }^{4-6}$

Acetamiprid [(E)-N-[(6-chloro-3- pyridyl) methyl]-N-cyano$\mathrm{N}$-methylacetamidine] is one of the most commonly used neonicotinoid class insecticides in many countries for crop pests on agricultural products. In general, acetamiprid has been considered a safe insecticide; however, several different adverse health effects may occur after exposure to acetamiprid as well as other neonicotinoids. ${ }^{3}$ In previous studies, it has been reported that acetamiprid showed teratogenic, mutagenic, and genotoxic effects via induction of oxidative stress. However, the data about its cyto- and genotoxic potentials are contradictory. ${ }^{7-12}$ As is well known, the worldwide rate of diabetes continues to rise, and the major molecular mechanisms underlying diabetes are increased oxidative stress and altered enzyme functions in pancreatic tissue..$^{3}$ Indeed, no association between diabetes risk and neonicotinoid pesticides has been reported. Furthermore, there has been no study on the toxic effects of acetamiprid on the pancreas. Therefore, for the first time, we aimed to investigate the cytotoxic and genotoxic effects of acetamiprid on the AR42J pancreatic cell line and evaluated its oxidative damage potential as an underlying molecular mechanism.

\section{MATERIALS AND METHODS}

\section{Chemicals}

Acetamiprid, dimethyl sulfoxide (DMSO), sodium dodecyl sulfate (SDS), 3-[4,5-dimethylthiazol-2-yl]-2,5-diphenyl-tetrazolium bromide (MTT), and 2',7'-dichlorodihydrofluorescein diacetate $\left(\mathrm{H}_{2}\right.$ DCF-DA) were purchased from Sigma Chemical Co. Ltd. (St. Louis, Missouri, USA). The cell culture medium [Roswell Park Memorial Institute (RPMI 1640)] and other chemicals were purchased from Multicell Wisent (Quebec, Canada), while the disposable materials were purchased from Corning (Amsterdam, the Netherlands). All other chemicals at required biological grade were purchased from Merck (New Jersey, USA).

\section{Cell culture and treatments}

The AR42J (CRL1492) cell line was obtained from the American Type Culture Collection (ATCC, Virginia, USA), and for all cell applications incubation was carried out according to the manufacturer's instructions. The cells were grown with
1640 cell culture medium including $10 \%$ fetal bovine serum, 100 $\mathrm{U} / \mathrm{mL}$ penicillin, and $100 \mathrm{mg} / \mathrm{mL}$ streptomycin in a humidified incubator in $5 \% \mathrm{CO}_{2}$ at $37{ }^{\circ} \mathrm{C}$. Subculturing was performed every 2-3 days when the cells reached confluence. Prior to exposure cells were seeded into appropriate plasticware and incubated overnight to ensure cell attachment.

Acetamiprid stock solution was prepared by dissolving in 100\% DMSO, and stored at $-20^{\circ} \mathrm{C}$ until the day the assays were conducted. Before the cell treatments acetamiprid was diluted with culture medium to the desired concentrations, and DMSO concentration finalized as $1 \%$. Treatments were performed at a concentration range for $24 \mathrm{~h}$ to evaluate dose-dependent effects. All experiments were performed in triplicate on three separate days.

\section{MTT cytotoxicity test}

The AR42J cells were placed into 96 -well plates $\left(1 \times 10^{4}\right.$ cells $/ 100$ $\mu \mathrm{L}$ cell culture medium/well). The cells were treated with acetamiprid following overnight incubation at the concentration range of $1-50 \mathrm{mM}$ for $24 \mathrm{~h}$. After $5 \mathrm{mg} / \mathrm{mL}$ MTT was added to each well, the cells were again kept for $3 \mathrm{~h}$ at $37^{\circ} \mathrm{C}$ in the dark. Cell culture medium was used as a growth control, $1 \%$ DMSO was used as a solvent control, and $10 \%$ SDS was used as a positive control. The wells were washed with poly (butylene succinate) (PBS) twice after $3 \mathrm{~h}$. Following the washing step, $100 \mu \mathrm{L}$ of DMSO was added, followed by incubation for $5 \mathrm{~min}$ on an orbital shaker $(150 \mathrm{rpm})$ for evenly dissolved formazan crystals and optical densities were measured using a microplate reader (Biotek, Epoch, Vermont, USA) at $570 \mathrm{~nm}$. The percentage of inhibition of cell viability for each concentration and the inhibitory concentration $50\left(\mathrm{IC}_{50}\right)$ value were determined.

\section{Comet genotoxicity assay}

AR $42 \mathrm{~J}$ cells were placed into 6 -well plate as $5 \times 10^{5} \mathrm{cells} / 2 \mathrm{~mL}$ cell culture medium/well and kept overnight for incubation. The cells were exposed to acetamiprid at 1, 2, 4, and $6 \mathrm{mM}$ concentrations and $1 \%$ DMSO as a negative control for $24 \mathrm{~h}$. After the cells were detached with trypsin-ethylenediaminetetraacetic acid (EDTA) and washed with PBS twice, the viability of cells was evaluated with the trypan blue test, and cell viability was determined as $\geq 80 \%$ for all concentrations. Next $100 \mu \mathrm{L}$ of single cell suspension was mixed with $100 \mu \mathrm{L}$ of prewarmed $0.65 \%$ lowmelting agarose and then layered on microscope slides coated with $1.5 \%$ normal-melting point agarose. After lysing for $1 \mathrm{~h}$ at $4^{\circ} \mathrm{C}$, the slides were incubated in cold fresh electrophoresis buffer $(0.3 \mathrm{M} \mathrm{NaOH}, 1 \mathrm{mM}$ EDTA, $\mathrm{pH} 13)$ at $4^{\circ} \mathrm{C}$ for $20 \mathrm{~min}$ for DNA unwinding. The electrophoresis conditions were $4^{\circ} \mathrm{C}$ for $20 \mathrm{~min}(20 \mathrm{~V} / 300 \mathrm{~mA})$. The slides were neutralized in $0.4 \mathrm{M}$ tris- $\mathrm{HCl}$ buffer ( $\mathrm{pH}$ 7.5). DNA staining was performed with 20 $\mathrm{mg} / \mathrm{mL}$ ethidium bromide dye and evaluated under a fluorescent microscope (Olympus BX53, Olympus, Tokyo, Japan) at 40x10 magnification by Comet Assay IV, Perceptive software (Suffolk, UK). One hundred cells were counted and scored for each concentration and \%TDNA and tail intensity were evaluated. ${ }^{14}$

\section{Oxidative stress parameters}

A total reactive oxygen species (ROS) assay was performed via (2'-7'-dichlorodihydrofluorescein diacetate) analysis by flow 
cytometry. Next $5 \times 10^{5}$ cells $/ 2 \mathrm{~mL}$ cell culture medium/well were placed into a 6-well plate. After one day of incubation, the cells were exposed to acetamiprid at 1, 2, 4, and $6 \mathrm{mM}$ concentrations and $1 \%$ DMSO as a negative control for $24 \mathrm{~h}$. After $24 \mathrm{~h}$ the plates were washed with PBS twice. The cells were incubated with $20 \mu \mathrm{M} \mathrm{H} \mathrm{H}_{2} \mathrm{DCF}-\mathrm{DA}$ at $37^{\circ} \mathrm{C}$ for 30 min on a shaker in the dark. They were detached from the plates via trypsinization and resuspended in $150 \mu \mathrm{L}$ of PBS with $1 \%$ bovine serum albumin. Fluorescence intensity was measured by FITC channel with excitation $488 \mathrm{~nm}$ and emission $530 \mathrm{~nm}$ via an ACEA NovoCyte flow cytometer (San Diego, California, USA). The results were shown as median fluorescence intensity.

Glutathione (GSH) levels were determined by [5,50-dithiobis2-nitrobenzoic acid) (DTNB)] reagent method described by Beutler. ${ }^{15}$ This method is based on DTNB reduction by free $\mathrm{SH}$ groups of GSH to 5-mercapto-2-nitrobenzoate. After treatment with acetamiprid, $1 \mathrm{~mL}$ of cell lysates was deproteinated with $1.67 \mathrm{~g}$ of metaphosphoric acid, $0.2 \mathrm{~g}$ of $\mathrm{Na}_{2}$ EDTA, and $30 \mathrm{~g}$ of $\mathrm{NaCl}$ solved in distilled water. After that, $2.4 \mathrm{~mL}$ of $\mathrm{Na}_{2} \mathrm{HPO}_{4}$ and $0.3 \mathrm{~mL}$ of DTNB were added, followed by centrifugation for $10 \mathrm{~min}$ at 3000x g. 5-Thio-2-nitrobenzoic acid formation was measured at $412 \mathrm{~nm}$ by spectrophotometer. GSH results were expressed as $\mu \mathrm{mol} / \mathrm{g}$ protein. ${ }^{15}$

\section{Statistical analysis}

The experimental results were analyzed by One-Way ANOVA post hoc Dunnett's t-test and given as mean \pm standard deviation. The level of statistical significance was set as $\mathrm{p} \leq 0.05$. All analyses were performed using SPSS version 20.0 (SPSS Inc., Chicago, Illinois, USA).

\section{RESULTS}

\section{Cell viability}

The MTT assay is one of the most frequently used, simple, and rapid colorimetric cell viability/cytotoxicity assays and yields quantitative data. This assay is based on reduction of water-soluble yellow tetrazolium salt by the mitochondrial succinate dehydrogenase enzyme in metabolically active/live cells dehydrogenase and quantified color intensity of dissolved formazan crystals by spectrophotometer. ${ }^{16}$

The cytotoxicity of acetamiprid on the AR42J cell line was evaluated with the MTT assay in the dose range of $1-50 \mathrm{mM}$ after $24 \mathrm{~h}$ exposure and the $\mathrm{IC}_{50}$ value was determined as 12.61 $\mathrm{mM}$ (Figure 1).

\section{Comet assay}

The alkaline comet assay is a very common method for measuring DNA damage in a single cell suspension via migration of DNA under electrophoresis conditions. It has been reported that the tail intensity value is the most recommended end point for an alkaline comet assay in a dose-dependent manner. ${ }^{17}$

According to the results of the comet assay in the concentration range of 1-6 mM, acetamiprid significantly increased DNA damage in a dose-dependent manner. The mean tail intensity values were significantly increased in all exposure groups compared to the control group (Figure 2).

\section{Oxidative stress parameters}

Oxidative damage via ROS plays a key role in different human diseases such as cancer, cardiovascular diseases, diabetes, and neurodegeneration. Dichlorodihydrofluorescein diacetate (DCFH-DA) is a widely used assay that enables direct measurement of the redox state in the cells. This method is very sensitive, easy to use, and cheap and can be used to follow changes in ROS over time. ${ }^{18}$

There were no significant differences between the control and exposure groups according to total ROS levels, which were evaluated by $\mathrm{H}_{2}$ DCF-DA with a flow cytometer. However, the GSH level was significantly reduced in the $6 \mathrm{mM}$ group compared to the control group. It was observed that $6 \mathrm{mM}$ of acetamiprid dramatically reduced GSH level by $98.07 \%$ (Figure 3).

\section{DISCUSSION}

Widespread use of acetamiprid in agriculture alone or in combination with other insecticides may cause pesticide spread into the environment and the food chain, resulting in toxicity in humans and animals. An increased risk of pancreatic

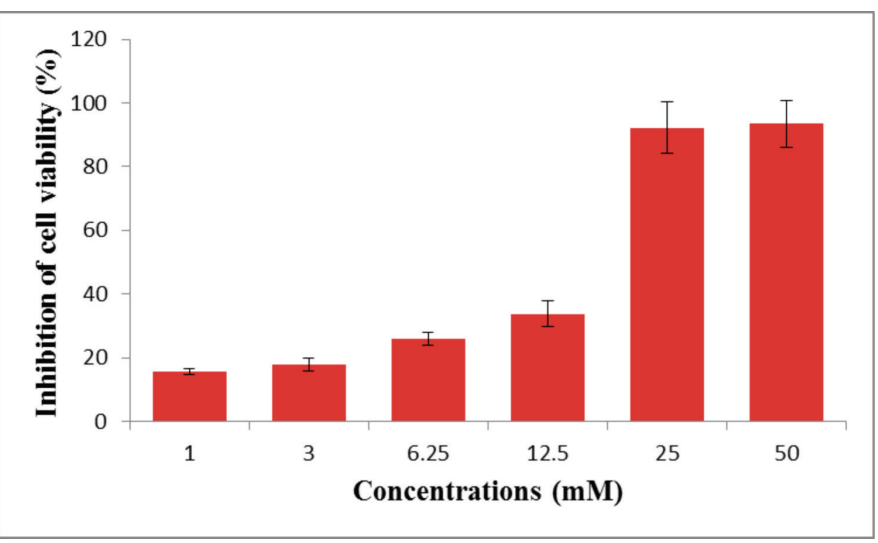

Figure 1. The inhibition of the cell viability values by MTT test in the AR42J cell line

MTT: 3-[4,5-dimethylthiazol-2-yl]-2,5 diphenyl tetrazolium bromide

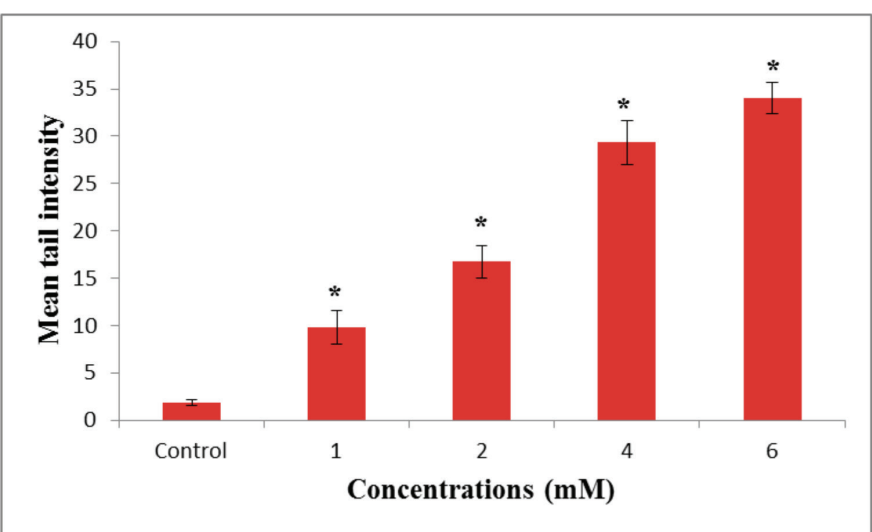

Figure 2. Acetamiprid-induced DNA damage in AR42J cell line at a concentration range of 1-6 mM as observed by comet assay. Representative single cell images clearly indicated that tail intensity was increasing while head of the cell was decreasing in a dose-dependent manner. The error bar represents \pm standard deviation and ${ }^{*} p<0.05$ compared to other groups 

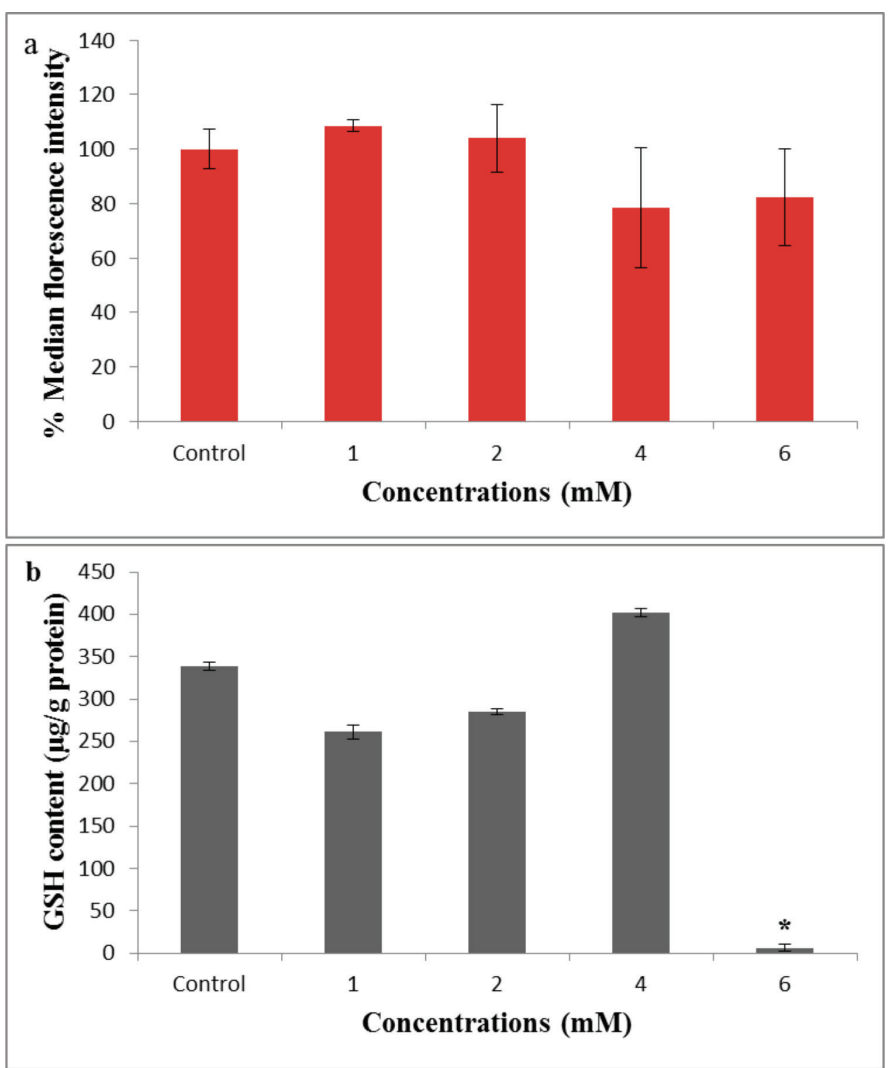

Figure 3. Oxidative damage potential of acetamiprid $(1,2,4$, or $6 \mathrm{mM})$ evaluated by $\mathrm{H}_{2}$ DCF-DA (a) and GSH (b) assays. The ROS production was expressed as mean fluorescence intensity and GSH levels were expressed as $\mu \mathrm{g} / \mathrm{g}$ protein. The error bar represents \pm standard deviation and * $\mathrm{p}<0.05$ compared to other groups

GSH: Glutathione, ROS: Reactive oxygen species, $\mathrm{H}_{2} \mathrm{DCF}-\mathrm{DA}$ : $2^{\prime}, 7^{\prime}$-dichlorodihydrofluorescein diacetate

cancer is found in those in agricultural occupations; however, pesticides' effects on oncogenesis mechanisms have not been extensively evaluated yet.19,20 There are limited data about the effects of neonicotinoids on pancreatic tissue; moreover, there are no data about acetamiprid's effects on the pancreas. Khalil et al. ${ }^{13}$ reported that 0.5 and $1.0 \mathrm{mg} / \mathrm{kg}$ bw imidacloprid over 60 days disrupted glucose homeostasis in male rats. In treated groups, the GLUT4 mRNA expression level was decreased and pancreatic islets shrinkage and infiltration of round cells, interlobular congestion, and hemorrhage were observed with histopathologic examination, and also decreased insulin expression in the pancreatic $\beta$ cells was detected in the imidacloprid-treated groups.

To further examine the potential associations between their usage and toxic profiles for neonicotinoid pesticides, we conducted a study on in vitro acetamiprid exposure in a pancreatic cell line. Although there are a few studies on acetamiprid's cyto- and genotoxicity potentials in the literature, there is no in vitro/in vivo study focusing on the pancreas. It has been reported that the $L D_{50}$ value is the range of $140-417$ $\mathrm{mg} / \mathrm{kg}$ b.w. in rodents and the NOAEL level is $400 \mathrm{ppm}$ in 13 week old mice for acetamiprid. ${ }^{21}$ It has been reported in another study that $\mathrm{IC}_{50}$ values of acetamiprid on SH-SY5Y and HepG2 cell lines were 2.16 and $3.61 \mathrm{mM}$, respectively. ${ }^{22}$ In our study, the cytotoxicity was evaluated by MTT assay in acetamiprid (1-50 $\mathrm{mM}$ ) treated AR42J cells after $24 \mathrm{~h}$ exposure. The $\mathrm{IC}_{50}$ value was calculated as $12.61 \mathrm{mM}$.

In the same study, significantly increased DNA damage was shown at $500 \mu \mathrm{M}$ in SH-SY5Y cells. ${ }^{22}$ In another study, >50 $\mu \mathrm{M}$ acetamiprid significantly increased micronuclei formation and DNA breaks in IMR-90 human lung cells. ${ }^{8}$ Genotoxic effects of acetamiprid on sister chromatid exchange, micronucleus, and chromosomal aberration analysis with $25,30,35$, and $40 \mu \mathrm{g} / \mathrm{mL}$ doses for 24 and $48 \mathrm{~h}$ were shown in human peripheral blood lymphocytes. Micronucleus formation was significantly induced compared to the control group while the proliferation index was decreased.12 It has been reported that acetamiprid increased micronuclei per cell and chromosomal aberrations in Swiss albino male mice bone marrow depending on concentration with acetamiprid treatment over 60 and 90 days at 4.6 and 2.3 $\mathrm{mg} / \mathrm{kg} /$ day i.p. ${ }^{23}$ According to the results of the comet assay performed with the concentration range of 1-6 mM, acetamiprid significantly induced DNA damage depending on concentration. The different results obtained from several studies can be related to cell types, study duration, and/or method selection.

Oxidative stress mechanisms could underlie the cyto- and genotoxic potentials of neonicotinoid pesticides. ${ }^{7,8,12}$ It has been reported that pesticides may impair the redox balance effects in different cells. However, the mechanisms underlying oxidative stress are still not fully understood. ${ }^{16}$ There are several studies about the effects of acetamiprid on oxidative stress parameters in different species such as rodents, bacteria, plants, and fish. ${ }^{24-}$ ${ }^{30}$ In Wistar rat brain tissue $3.14 \mathrm{mg} / \mathrm{kg}$ acetamiprid exposure resulted in increased mitochondrial oxidative stress status that was significant. Decreased oxidative stress parameters were GSH level, GSH peroxidase, and catalase activities. Increased parameters determined were malondialdehyde level, GSH s-transferase, and superoxide dismutase activities. ${ }^{31}$ In our study, no significant difference was found between the control and exposure groups according to total ROS levels. However, the GSH levels were significantly different compared to the control at the highest concentration. It was observed that $6 \mathrm{mM}$ acetamiprid dose dramatically reduced GSH level by $98.07 \%$. In earthworms, it has been demonstrated that different concentrations of acetamiprid (0, 0.05, 0.10, 0.25, and $0.50 \mathrm{mg} / \mathrm{kg}$ of soil) with different exposure periods (7, 14, 21 , and 28 days) increased the ROS levels to varying degrees. Olive tail moment, which indicates DNA damage in the comet assay, increased in a dose-dependent manner, indicating that subchronic acetamiprid exposure might cause oxidative stress and induce DNA damage in earthworms. ${ }^{24}$

Acetamiprid is classified as an "unlikely" human carcinogen according to EPA guidelines and its target organ toxicity data are not clear yet. Acetamiprid's acute oral toxicity category is "II" for rats and its acute inhalation toxicity category is "III" for rabbits. Its NOAEL value for rats is $12.4 / 14.6 \mathrm{mg} / \mathrm{kg} /$ day $(M / F)$ and its LOAEL value for rat is $50.8 / 56.0 \mathrm{mg} / \mathrm{kg} / \mathrm{day}(\mathrm{M} / \mathrm{F})$. The chronic carcinogenicity NOAEL value for rats is $7.1 / 8.8 \mathrm{mg} /$ 
$\mathrm{kg} /$ day $(\mathrm{M} / \mathrm{F})$. According to the EPA acetamiprid is not yet classified as genotoxic. ${ }^{32} \mathrm{~A}$ target organ toxicity assessment for further subchronic and chronic in vivo studies may clarify the risk caused by acetamiprid for pancreas tissue-based diseases.

\section{CONCLUSION}

Under different durations in the pancreatic cell line acetamiprid may affect these oxidative stress parameters significantly. To clarify the oncogenic potential of acetamiprid on pancreatic tissue it is necessary to perform further in vivo studies with subchronic or chronic studies with molecular mechanistic observations.

Conflicts of interest: No conflict of interest was declared by the authors. The authors alone are responsible for the content and writing of the paper.

\section{REFERENCES}

1. Hamadache M, Benkortbi O, Hanini S, Amrane A, Khaouane L, SI Moussa C. A quantitative structure activity relationship for acute oral toxicity of pesticides on rats: validation, domain of applicationandprediction. J Hazard Mater. 2016;303:28-40.

2. Speck-Planche A, Kleandrova VV, Luan F, Cordeiro MND. Predicting multiple ecotoxicological profiles in agrochemical fungicides: a multi-species chemo informatic approach. Ecotoxicol Environ Saf. 2012;80:308-313.

3. Chakroun S, Ezzi L, Grissa I, Kerkeni E, Neffati F, Bhouri R, Sallem A, Najjar MF, Hassine M, Mehdi M, Haouas Z, Cheikh HB. Hematological, biochemical, and toxicopathic effects of subchronic acetamiprid toxicity in Wistar rats Environ Sci Pollut Res Int 2016;23:25191-25199.

4. Çavaș T, Çinkıııç N, Vatan Ö, Yılmaz D. Effects of fullerenol nanoparticles on acetamiprid induced cytoxicity and genotoxicity in cultured human lung fibroblasts. Pestic Biochem Physiol. 2014;114:1-7.

5. Cimino AM, Boyles AL, Thayer KA, Perry MJ. Effects of neonicotinoid pesticide exposure on human health: a systematic review. Environ Health Perspect. 2017;125:155-162.

6. Mikolić A, Karačonji IB. Imidacloprid as reproductive toxicant and endocrine disruptor: investigations in laboratory animals. Arh Hig Rada Toksikol. 2018;69:103-108.

7. Al-Sarar AS, Abobakr Y, Bayoumi AE, Hussein HI. Cytotoxic and genotoxic effects of abamectin, chlorfenapyr, and imidacloprid on CHOK1 cells. Environ Sci Pollut Res. 2015;22:17041-17052.

8. Çavaş T, Çinkılıç N, Vatan Ö, Yılmaz D, Coșkun M. In vitro genotoxicity evaluation of acetamiprid in $\mathrm{CaCo}-2$ cell susing the micronucleus, cometand $\gamma \mathrm{H} 2 \mathrm{AX}$ fociassays. Pestic Biochem Physiol 2012;104:212-217.

9. Caldero'n-Segura ME, Go'mez-Arroyo S, Villalobos-Pietrini R, MartínezValenzuela C, Carbajal-López Y, del Carmen Calderón-Ezquerro M, Cortés-Eslava J, García-Martínez R, Flores-Ramírez D, RodríguezRomero MI, Méndez-Pérez P, Bañuelos-Ruíz E. Evaluation of genotoxic and cytotoxic effects in human peripheral blood lymphocytes exposed in vitro to neonicotinoid insecticides news. J Toxicol. 2012:612647.

10. Demsia G, Vlastos D, Goumenou M, Matthopoulos DP. Assessment of the genotoxicity of imidacloprid and metalaxyl in cultured human lymphocytesandrat bone-marrow. Mutat Res Genet Toxicol Environ. 2007;634:32-39.
11. Feng $\mathrm{S}$, Kong Z, Wang $\mathrm{X}$, Peng $\mathrm{P}$, Zeng EY. Assessing the genotoxicity of imidacloprid and $\mathrm{RH}-5849$ in human peripheral blood lymphocytes in vitro with comet assay and cytogenetic tests. Ecotoxicol Environ Saf. 2005;61:239-246.

12. Kocaman AY, Topaktaş M. In vitro evaluation of the genotoxicity of acetamiprid in human peripheral blood lymphocytes. Environ Mol Mutagen. 2007;48:483-90.

13. Khalil SR, Awad A, Mohammed HH, Nassan MA. Imidacloprid insecticide exposure induces stress and disrupts glucose homeostasis in male rats. Environ Toxicol Pharmacol. 2017;55:165-174.

14. Singh NP, McCoy MT, Tice RR, Schneider EL. A simple technique for quantitation of low levels of DNA damage in individual cells. Exp Cell Res. 1988;175:184-191.

15. Beutler E. Red Cell Metabolism. In: A manual of Biochemical Methods. $2^{\text {nd }}$ ed. New York, NY: Grunneand Stratton: 1975;71-73.

16. Karakaş D, Ari F, Ulukaya E. The MTT viability assay yields strikingly false-positive viabilities although the cells are killed by some plant extracts. Turk J Biol. 2017;41:919-925.

17. Kennedy EK, McNamee JP, Lalonde LP, Jones T, Wilkinson D. Acellular comet assay: a tool for assessing variables influencing the alkaline comet assay. Radiat Prot Dosimetry. 2012;148:155-161.

18. Eruslanov E, Kusmartsev S. Identification of ROS using oxidized DCFDA and flow-cytometry. Methods Mol Biol. 2010;594:57-72.

19. Andreotti G, Freeman LE, Hou L, Coble J, Rusiecki J, Hoppin JA, Silverman DT, Alavanja MCR. Agricultural pesticide use and pancreatic cancer risk in the Agricultural Health Study Cohort. Int J Cancer. 2009; 15:124:2495-2500.

20. Caron-Beaudoin É, Denison MS, Sanderson JT. Effects of neonicotinoids on promoter-specificexpressionand activity of aromatase (CYP19) in human adrenocortical carcinoma (H295R) and primary umbilical vein endothelial (HUVEC) Cells Toxicol Sci. 2016;149:134-144.

21. FAO, Food and Agriculture Organization of the United Nations. Last Accessed Date: 6.12.2018 Available from: http://www.fao.org/fileadmin/ templates/agphome/documents/Pests_Pesticides/JMPR/Report11/ Acetamiprid.pdf

22. Șenyildiz M, Kilinc A, Ozden S. Investigation of the genotoxic and cytotoxic effects of widely used neonicotinoid insecticides in HepG2 and SH-SY5Y cells. Toxicol Ind Health. 2018:1-9.

23. Bagri P, Jain SK. Assessment of acetamiprid-induced genotoxic effects in bone marrowcells of Swiss albino malemice. Drug Chem Toxicol. 2018;6:1-7.

24. Li B, Xia X, Wang J, Zhu L, Wang J, Wang G. Evaluation of acetamipridinduced genotoxic and oxidative responses in Eiseniafetida. Ecotoxicol Environ Saf. 2018;19:610-615.

25. Quintana MM, Rivero Osimani V, Magnarelli G, Rovedatti MG, Guiñazú N. The insecticides chlorpyrifos and acetamiprid induce redox imbalance in umbilical cord blood erythrocytes in vitro. Pestic Biochem Physiol. 2018;148:87-92

26. Wang Y, Wu S, Chen J, Zhang C, Xu Z, Li G, Cai L, Shen W, Wang Q. Single and joint toxicity assessment of four currently used pesticides to zebrafish (Danio rerio) using traditional and molecular endpoints. Chemosphere. 2018;192:14-23.

27. Dhouib IB, Annabi A, Doghri R, Rejeb I, Dallagi Y, Bdiri Y, Lasram MM, Elgaaied A, Marrakchi R, Fazaa S, Gati A. Neuroprotective effects of 
curcumin against acetamiprid-induced neurotoxicity and oxidative stress in the developing male rat cerebellum: biochemical, histological, and behavioral changes. Environ Sci Pollut Res Int. 2017;24:27515-27524.

28. Yu X, Lu W, Sun R, Guo X, Xu B. Identification and characterization of a novel calcyclinbinding protein (CacyBP) gene from Apisceranacerana. Mol Biol Rep. 2012;39:8053-80563.

29. Ford KA, Gulevich AG, Swenson TL, Casida JE Neonicotinoid insecticides: oxidative stress in planta and metallo-oxidase inhibition J Agric Food Chem. 2011;59:4860-4867.

30. Yao XH, Min H, Lv ZM. Response of superoxide dismutase, catalase, and ATPase activity in bacteria exposed to acetamiprid. Biomed Environ Sci. 2006;19:309-314.
31. Gasmi S, Kebieche M, Rouabhi R, Touahria C, Lahouel A, Lakroun Z, Henine S, Soulimani R. Alteration of membrane integrity and respiratory function of brain mitochondria in the rats chronically exposed to a low dose of acetamiprid. Environ Sci Pollut Res Int. 2017;24:22258-22264.

32. EPA, United States Environmental Protection Agency. Pesticide Fact Sheet, Acetamiprid. Last Accessed Date: 20.01.2019 Available from: https://www3.epa.gov/pesticides/chem_search/reg_actions/ registration/fs_PC-099050_15-Mar-02.pdf 